\title{
2210 高速鉄道車両の車輪・レール接線カに関する新たなモデル化手法の研究
}

\author{
A Study on Alternative Tangential Force Modelling for High Speed Railway Vehicles
}

\section{O正 佐々木浩一（J R 東日本） 正 須田義大（東京大学）}

\author{
Koichi SASAKI, East Japan Railway Nishin-cho 2-0 Kita-ku Saitama-shi, SAITAMA 331-8513 \\ Yoshihiro SUDA, University of Tokyo
}

\begin{abstract}
The modeling methods as dynamics analysis was considered about the wheel/rail tangential force which affects various running ability of high speed railway vehicles, such as running stability, comfort, curving negotiation, and safety to derailment. In the case of a high speed railway, the driving force which balances to the train resistance is needed, even when running at the constant speed. So the traction force and the spin, in the quasi- state running condition, influence the saturation characteristics of wheel/rail tangential force, and generate the error which cannot be disregarded to lateral oscillation analysis of driven vehicles. Two alternative models in consideration of traction force and the spin of wheel /rail tangential force are devised. As a result of verifying by comparison with a real vehicle run, the necessity of raising the accuracy of analysis further was accepted. Nevertheless, the second method would be fully equal to use as a good approximation.
\end{abstract}

キーワード：高速鉄道車両，車輪・レール接触カ，モデリング，左右振動解析，車両ダイナミクス Key Word : High speed railway vehicle, Wheel/Rail tangential force, modeling, Lateral vibration analysis, Vehicle dynamics

1 .

粕

最高速度 $300 \mathrm{~km} / \mathrm{h}$ の営業運転を行う高速鉄道がフランス, ドイツなど欧州諸国をはじめとして, 日本, 韓国などで経 営的にも成果を収め，これからも様々な諸国において路線 が拡大する状況となっている。さらにはスペイン，フラン スなどで最高速度 $330 \sim 350 \mathrm{~km} / \mathrm{h}$ といった新規の高速新線 の計画が具体性あるスケジュールとして公表されている。

このような状況において, 高速鉄道車両としては, 安全 に走行することは大前提であり,さらにより優れた走行安 定性・振動乗り心地性能を有することが，これからも求め られるものと考えられる。

本論文では, 走行安定性・振動乗り心地に限らず, 曲線 旋回性能, 脱線に対する安全性など, 高速鉄道車両のあら ゆる走行性能に影響を及ぼす車輪・レール接線力に関して, ダイナミクス解析としてのモデル化手法について検討を行 ったことなどについて述べる。

\section{2. 車輪・レール接線カに関する従来モデル}

周知のように, 1964 年の東海道新幹線の開業にあたって 新幹線電車はいわゆる動力分散の電動車（ $\mathrm{M}$ 車）方式を基 本として構成され, その後, 次第に動力を有しない付随車 （T 車）を一部に設ける方式となっている．のちに開業し たフランスの TGV は, 日本方式への改善を考慮し, かつ 機関車十客車列車を主体とする従来の動力集中方式の延長 線上で, 軸重が小さくなる付随客車を連節方式とすること により，2 軸ボギ一方式の機関車との軸重の均等化を行っ て，軌道負担低減をはかった構成としたささらに，ドイツ の ICE-3 は，日本およびフランスの両方式の長所を発展さ せ, 編成の自由度を増加させて様々な運行形態にも適応で
きる方式として，M 車と $\mathrm{T}$ 車の比率を 1 対 1 の最小限のユ ニット構成とし, かつ $\mathrm{T}$ 車に重量のある電源機器等を搭載 するなどして軽量化と軸重の均等化をはかった方式として いる.

サスペンションの構成に関しては, TGV は, 連節方式の 利点を活用して左右方向の支持中心高さを通常の 2 軸ボギ 一方式よりも高くし, 軸距 $3 \mathrm{~m}$ とするなど走行安定性の限 りない向上をはかったものとし，また，ICE-3 は，軸距 2.5 $\mathrm{m}$ と日本方式と同じで，世界標準となりつつある軸はり式 ボルスタレス・アンチロールスタビライザー付きボギー台 車などとしている.

このような車両構成への評価のひとつとして, 簡易な測 定器による営業車の車体左右振動の実測結果を示す（Fig.1, 2). どちらも, 測定位置は台車中心位置付近の床面であり, ISO2631 に基づく JR 方式乗り心地評価方法で評価すると, 重み付き実効加速度レベルが $83 \mathrm{~dB}$ と「非常に良い」とい う振動ランクとなっている.

また，これらの振動パワースペクトル密度をみると，日 本の場合との相違点は $1 \sim 2 \mathrm{~Hz}$ 付近のいわゆる「低周波車 体左右動摇」が極端に小さくなっていること, また， $30 \mathrm{~Hz}$ 程度までの高周波数領域で, 弾性振動によるピークが ICE-3 ではほとんどない状況となっていること, さらに, そのような振動性能を「アクティブ動摇防止制御を行わず」 に実現していることなどがある。

こうした状況をふまえ, 車両のサスペンション設計, 開 発ならびにその基本的な解析手段である車両ダイナミクス 解析に関する理論展開, とくに車輪・レール接線力 (Creep 力）特性の解析などが, これまでどのように発展してきた かを振り返ることとする。

〔No.05-52] 日本機械学会第 14 回交通・物流部門大会講演論文集〔2005-12.7～9. 川崎〕 


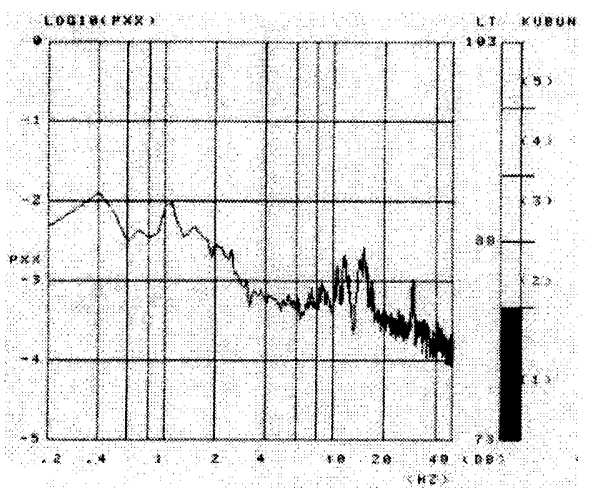

Fig.1 P.S.D. of lateral car-body acceleration, measured on TGV- Mediterranean in Jul. 01 (max. speed $300 \mathrm{~km} / \mathrm{h}$ )

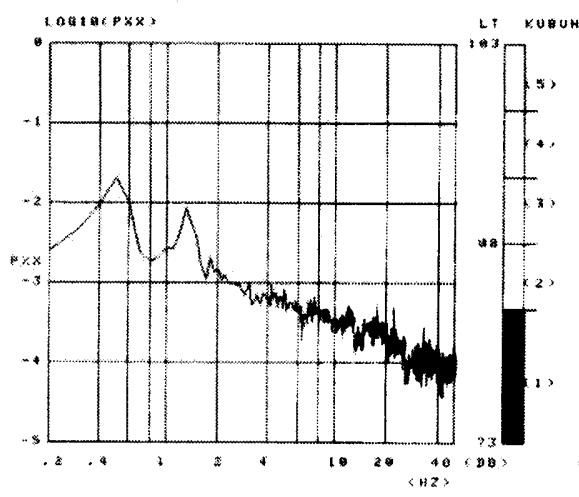

Fig.2 P.S.D. of lateral car-body acceleration, measured on ICE-3 (coach) in Jul. 01 (max. speed $250 \mathrm{~km} / \mathrm{h}$ )

輪軸のだ行動に関する理論解析は，古くは 1873 年の Klingerの式にさかのぼり, その後, 高速鉄道に関しては, 東海道新幹線の開業時の旧 JNR 技術研究所によるものな どがある(例えば1)など)。このときのCreep 力特性は, Heltzによる接触だ円理論を基本として $1 / 5$ 模型実験などに よる修正を加えるなどとしたものとなっている，現時点ま でもっとも有力な理論は，車輪踏面におけるスピン横方向 力を考慮するなど，それまでの理論を集大成した Delft 大 学 Kalker 教授によるものがある ${ }^{2)}$. 非線形・時刻歴シミュ レーション解析での使用を前提とした計算手法となってい て, 解析用 Package Software などが市販されているが，欧 州を中心とした高速鉄道車両開発に伴って作成されたもの で，一般には解析コードが未公開のため, 詳細は不明であ る.

これらの Softwareや Kalker 理論などを用いて高速鉄道車 両の振動解析を実施しようとする場合に，その前段で障壁 となりうることがらが存在する。多くの場合，飽和特性の 最大値である摩擦力（粘着力）に対して無次元化している 車輪・レール接線力を実際に求めるためには, 摩擦係数 $\mu$ をどのように扱えばよいのか，また，走行抵抗に拮抗する 駆動力および Kalker 理論のスピン横方向力などを無視し た解析を行ってよいのか, ということなどである.

これまで, 低速の曲線走行性能への駆動力の影響 ${ }^{3)}$ を述 べたものなどはあるが，高速鉄道についてはない。

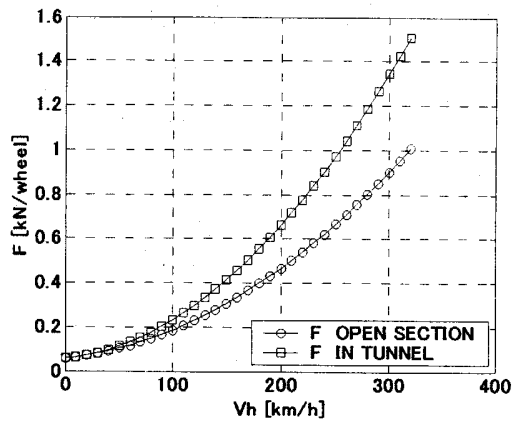

Fig.3 Traction Forces acting on a wheel, estimated by measurement of train deceleration

3. 準定常走行状態における車輪・レール接線力

まず，軌道不整による車輪・レール接線力は作用せず， 一定の速度で走行し輪軸には駆動力が作用するという状態 を考える．高速鉄道車両の場合には，一定の速度で走行し ている場合でも, 走行速度の 2 乗に比例して増大する空気 抵抗を主体とする走行抵抗に拮抗する駆動力が必要である。 その力は, 前後方向に作用する車輪・レール接線力によっ ている.ささらに，車輪・レール接触面において接触勾配に よるスピン横方向力が，左右車輪で大きさが同じで逆方向 という状態で作用する。一対の輪軸としては内力となるの で，輪軸に左右変位を生じさせない，この状態を準定常走 行状態と呼ぶことにする.

走行抵抗は，実車走行試験において実測する。無駆動の 状態で減速度を測定し，勾配補正や統計処理を行って「走 行抵抗式」として求める. Fig3 に走行抵抗式から求めた駆 動軸に作用する前後方向力の例を示す。

解析コードが公開されている Fastsim ${ }^{4)}$ を用いて，中立 位置における接触勾配が $1 / 40$ の新幹線円弧踏面で, $300 \mathrm{~km} / \mathrm{h}$ 走行時の準定常走行状態における右車輪の場合の 車輪・レール接線力として求めた結果を Fig4 に示す. 左車 輪の場合は上下対称の分布となる． $\mathrm{x}$ 軸方向に作用する駆 動力, 反フランジ方向に作用するスピン横方向力ならびに スピンモーメントが計算される.

これらの車輪・レール接線力は, 左右車輪で一対の輪軸 において内力となり，輪軸を横移動もしくは回転させる力 とはならない。しかし，車輪・レール接線力の飽和特性を 考慮するためには無視できないものとなる。

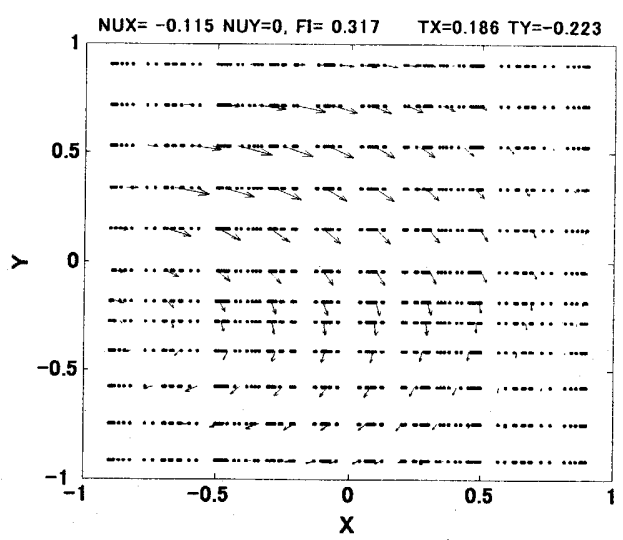

Fig.4 Forces distributed on wheel/rail contact patch calculated by Fastsim, with Traction and Spin in the quasi-static condition of high-speed running 


\section{4. 新たな車輪・レール接線カモデルの定式化}

Kalker もしくは Shen/Hedrick/Elkins ${ }^{5)}$ の車輪・レール接 線力モデルは,

$\left(F_{x}, F_{y}\right)=\left(F / \omega^{\prime}\right) \cdot\left(\xi^{\prime}, \eta^{\prime}\right)$

$F=\mu N\left[1-\left(1-\omega^{\prime}\right)^{3}\right] \quad \omega^{\prime} \leq 1$

とあらわされる。ここで， $\xi^{\prime}, \eta^{\prime}, \psi, \omega^{\prime}$ などは無次元クリ

一プ率，スピンなどを表す。

この式において，準定常走行状態を考慮して，駆動力お よびスピン横方向力を作用させた場合の式は，

$\left.F=\mu N \mid 1-\left(1-\left(\omega^{\prime}-\omega_{T R}^{\prime}\right)\right)^{3}-F_{T R}\right]$

となる。ここで， $\omega_{T R}^{\prime}, F_{T R}$ は，準定常走行状態における クリープ率, 駆動力などを示す.

さらに，車輪・レール接線力係数比は，飽和特性に対する 記述関数として

$$
\begin{aligned}
\varepsilon_{C R F} & =\left(1-\omega_{T R}^{\prime}\right)^{2}-8 / 3 \pi \cdot\left(1-\omega_{T R}^{\prime}\right) \omega^{\prime}+1 / 4 \cdot \omega^{\prime 2} \\
& +4 / 3 \pi \cdot\left[F_{T R}-\left\{1-\left(1-\omega_{T R}^{\prime}\right)^{3}\right\}\right] / \omega^{\prime}
\end{aligned}
$$

と求めることができる.

また，Vermeulen＆Johnson ${ }^{6)}$ による車輪・レール接線力 モデルの考え方により，準定常走行状態を定式化した場合 は,

$$
F=\mu N\left(1-{ }_{q s} F_{C R F}\right) \cdot\left(1+3 \omega^{\prime \beta}\right)^{-1 / \beta}
$$$$
{ }_{q s} F_{C R F}=\left|F_{T R} / \mu N, \psi\right|, \quad \omega \leq 1
$$

となる。同様に，車輪・レール接線力係数比は，

$\varepsilon_{C R F}=\left(1-{ }_{q s} F_{C R F}\right) \cdot\left(1+3 \omega^{\prime \beta}\right)^{-1 / \beta}$

として求めることができる。但し，以下では $\beta=1.0$ とした.

以上，いずれの場合も，準定常走行状態を考慮した車輪・ レールの接触面におけるすべり率（Creepage，Spin）の振 幅に依存した接線力の算出式として，高速鉄道車両の左右 振動解析に用いることができる.

\section{5. 左右振動系解析に与える誤差とその影車}

Kalker 理論などにおいて, 無次元指数における摩擦係数 $\mu$ をどのような値とすべきかの議論はない，これについて は，ブレーキ制御にかかわる文献などでよく扱われ，その 場合は粘着係数と呼ばれる。新幹線開業以来，雨天時の粘 着係数下限値として，走行速度に関する粘着係数は，

$\mu=13.6 /\left(V_{H}+85\right)$

という実験式が用いられる，通常の晴天時の粘着係数につ いては，実測值を整理したものはないので，欧州規格など も勘案して,

$\mu=13.6 /\left(V_{H} / \kappa_{m u}+85\right), \quad \kappa_{m u}=5$

という式を用いることとした。

左右振動系解析モデルは，17 自由度の 1 車両，車体弾性 は考慮せず，サスペンション要素はすべて線形として取り 扱っている，軌道不整は，左右（通り）上ロール（水準） 2 方向の空間周波数スペクトル分布を実測值から仮定し，
車体左右振動加速度スペクトル密度を算出して, 実車走行 の測定値との比較を行った.

その例として，300km/ $\mathrm{h}$ 走行時の実測値（Fig.5），準定常 走行状態を考慮しない場合の計算值（Fig.6），式(3)による 準定常走行状態を考慮した場合の計算值（Fig.7），ならび に式(5)による準定常走行状態を考慮した場合の計算值 （Fig.8）などを示す.パワースペクトル密度で比較すると， 計算方法によって $1 \sim 2 \mathrm{~Hz}$ の「低周波車体左右動摇」をう まく表現できているものと，そうではないものがあること がわかる。

Fig.5 の実測波形の特徵は，「低周波車体左右動摇」とし て $1 \sim 2 \mathrm{~Hz}$ に振動ピークがあること，10 数 $\mathrm{Hz}$ に車体弾性 振動があらわれていること, $30 \mathrm{~Hz}$ に車輪の回転周波数に相 当する振動があること，などである。これらのうち「低周 波車体左右動摇」は，Fig.1〜2の例では大きなピークとは なっていない。

式(1)に相当する車輪・レール接線力モデルとして，式(3) において $\omega_{T R}^{\prime}=0, F_{T R}=0$ などとすると, 準定常走行状態 を考慮しない結果が得られる（Fig.6）。この場合は， $\varepsilon_{C R F}=0.82$ となる.「低周波車体左右動摇」のピーク振動

数は, $2.5 \mathrm{~Hz}$ 付近となり実際より高周波数側と計算され, 1 〜 $2 \mathrm{~Hz}$ 領域はむしろピークが下がって，現象を再現できて いないことがわかる。

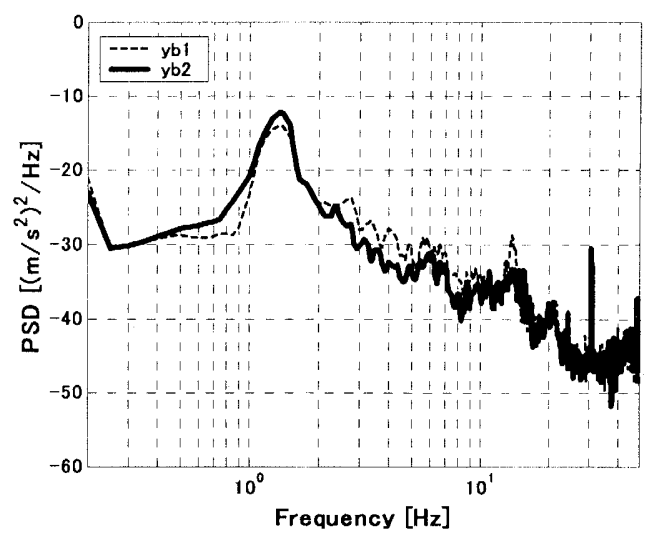

Fig.5 Measured P.S.D of lateral car-body acceleration, on a Shinkansen train of JR-EAST,

(ybl : on front bogie, yb2: on rear bogie)

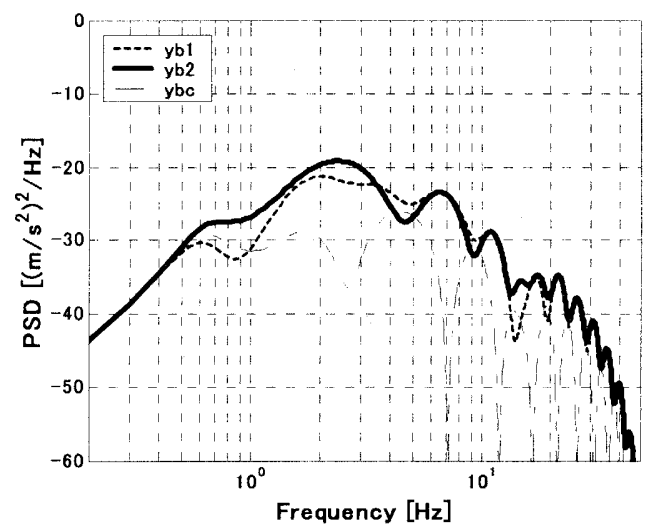

Fig.6 Calculated P.S.D of lateral car-body acc., without the consideration of Traction and Spin, (yb1, yb2: same as Fig.5, ybc : body center) 


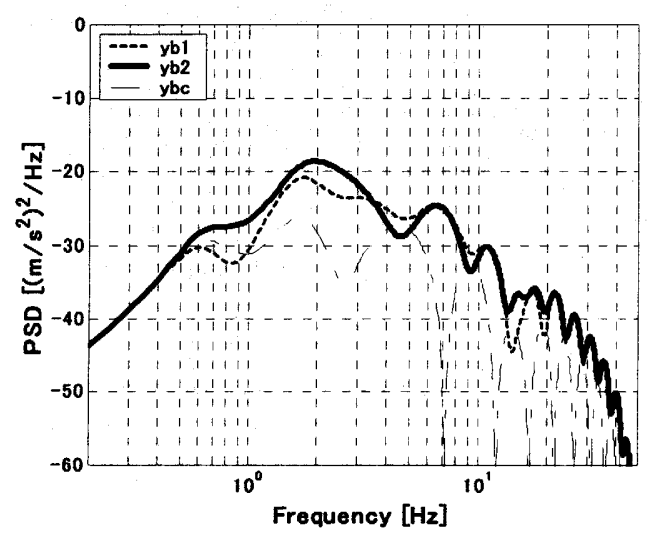

Fig.7 Calculated P.S.D of lateral car-body acc., with the consideration of Traction and Spin, by means of the primary proposal method(Equ.(3)) (yb1, yb2, ybc : same as Fig.6)

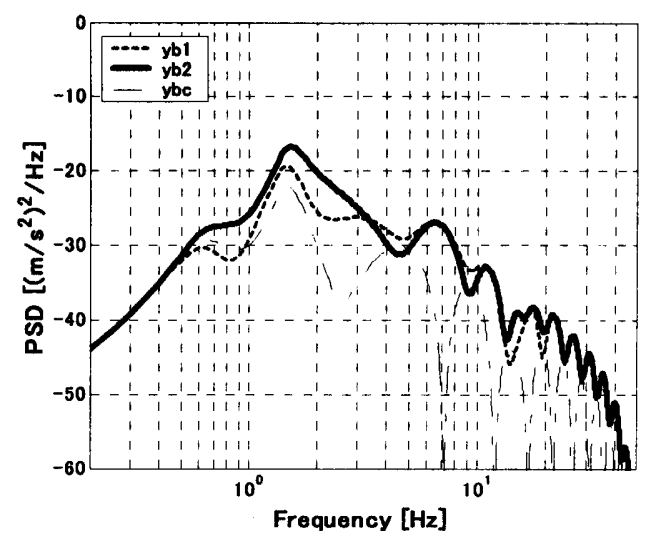

Fig.8 Calculated P.S.D of lateral car-body acc., with the consideration of Traction and Spin, by means of the secondary proposal method(Equ.(5)) (yb1, yb2, ybc : same as Fig.6)

式(2)および式(3)であらわされる準定常走行状態を考慮 した車輪・レール接線カモデルを用いた場合の結果 (Fig.7) では， $\varepsilon_{C R F}=0.66$ と計算され，「低周波車体左右動摇」の ピーク振動数は, $2.0 \mathrm{~Hz}$ 付近となる.

さらに，式(4)，(5)による同様の結果（Fig.8）では, $\varepsilon_{C R F}=0.48$ と計算され,「低周波車体左右動摇」のピーク

振動数は, $1.5 \mathrm{~Hz}$ 付近までさがる.

以上のように，車輪・レール接線力のモデル化手法によ って,「低周波車体左右動摇」のピーク振動数を再現できる かどうかに影響する。これは, 車輪・レール接線力係数に より, Whickens ${ }^{7)}$ による「操舵モード (Steering mode)」 の固有振動数と減衰比が影響を受けるためである.

この振動数領域は，振動乗り心地の良否評価においても っとも重要とされ, 高速鉄道車両のサスペンション設計に おいて, 以上のような配慮がない場合は, 適正值とは異な る解に導かれてしまうことを示している。

また，以上の議論において，もし仮に，摩擦係数 $\mu$ がさ らに数倍大きな值をとるなどと仮定した場合には，車輪・ レール接線力係数がさらに大きな值となり, 飽和特性を考
慮しないKalkerの線形理論で求められる値に収斂すること になるので,「低周波車体左右動摇」のピーク振動数はさら に高周波数側に移動して誤差を拡大することになる.

また, Kalkerの理論式から求めた式(1)などで, 誤差が存

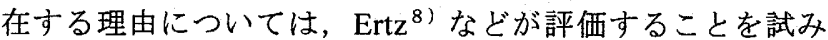
ており，車輪の表面粗さ，表面温度が影響するなどとして いる。

さらなる詳細な車輪・レール接線力に関するモデル化手 法については, 今後の検討課題となるが, 式(5)を用いた解 析を行うことにより，近似解法としてはより精度が向上し ているので，様々な解析検討に用いることができるものと 考えられる。

6

安全に走行することは大前提で，さらにより優れた走行 安定性・振動乗り心地性能を有することが求められる高速 鉄道車両について，あらゆる走行性能に影響を及ぼす車 輪・レール接線力に関して，ダイナミクス解析としてのモ デル化手法について検討を行った.

その結果, 以下のことがわかった。

1) 欧州における高速鉄道車両の車体左右振動加速度の実 測例を示し,「アクティブ動摇防止制御」を行っていない場 合でも，低周波車体左右動摇がほとんど認められないこと を示した。

2) Kalker 理論をはじめとするこれまでの車輪・レール接 線力の計算手法では, 飽和特性の最大摩擦力をどのように 見積もるかなど，実用上の難点がある。

3) 高速鉄道の場合，一定速度で走行する場合でも空気抵 抗などに拮抗する駆動力を必要とする，準定常走行状態に おける駆動力と車輪踏面のスピン横方向力は，車輪・レー ル接線力の飽和特性に影響し，駆動軸の場合の左右振動解 析に無視できない誤差を生じる.

4) 駆動力とスピン横方向力による車輪・レール接線力の 飽和特性への影響を考慮した 2 方式のモデル化手法を提案 し, 左右振動解析を行って計算精度の評価を行った。

5)これらの計算手法では，さらなる精度向上の必要性が 認められるが，ひとつの計算手法については，近似解法と しては, より精度が向上しているので, 様々な解析検討に 用いることができるものと考えられる。

6) 駆動力とスピン横方向力による車輪・レール接線力の 飽和特性への影響を無視できないことがわかった。

\section{文献}

1)横瀬, 車輪とレールのすべり現象について, 機論(第 3 部)37 巻 304 号 1970/12

2) Kalker J.J, Three-Dimensional Elastic Bodies in Rolling Contact, Kluwer Academic Print 1991/02

3)須田 Grencik，鉄道車両における駆動・制動力の曲線旋回性能 一の影響, 機論 C62 巻 596 号 1996/4

4) Kalker J.J, A Fast Algorithm for the Simplified Theory of Rolling Contact, Vehicle System Dynamics 11(1982), p1-13

5) Shen Hedrick \& Elkins, A Comparison of Alternative Creep Force Models for Railway Vehicle Dynamic Analysis Proc $8^{\text {th }}$ IAVSD 1983

6) Vermeulen Johnson, Contact of nonspherical elastic bodies transmitting tangential forces, J. Applied Mechanics 311964

7) Wickens,A.H, Fundamentals of Rail Vehicle Dynamics, Swets \& Zeitlinger Publishers 2003

8) Ertz $M$, Improved Creep Force Model for Wheel/Rail Contact Considering Roughness and Temperature, Proc $17^{\text {th }}$ IAVSD 2001/08 